\title{
Strategi Imperialisme British dalam Dasar Desentralisasi Negeri-Negeri Melayu Bersekutu, 1927-1934
}

\section{The British Imperialism Strategy in Federated Malay States' Decentralisation Policy, 1927-1934}

\author{
*MOHD SHAZWAN MOKHTAR \\ MOHD SAMSUDIN \\ SUFFIAN MANSOR
}

History Programme, Research Centre for History, Politics and International Affairs, Faculty of Social Sciences and Humanities, Universiti Kebangsaan Malaysia, Bangi, Malaysia

*Corresponding author: msm@ukm.edu.my

Published online: 31 May 2021

To cite this article: Mohd Shazwan Mokhtar, Mohd Samsudin and Suffian Mansor. 2021. Strategi imperialisme British dalam dasar desentralisasi Negeri-Negeri Melayu Bersekutu, 1927-1934. KEMANUSIAAN the Asian Journal of Humanities 28(1): 99-126. https://doi.org/10.21315/ kajh2021.28.1.5

To link to this article: https://doi.org/10.21315/kajh2021.28.1.5

\begin{abstract}
This article re-examines the argument for the decentralisation policy in restoring the Malay Rulers' power at the State Councils in the Federated Malay States (FMS). It focuses on the early phase of the policy implementation, i.e. after the Federal Council reconstitution in 1927 until its full execution in 1934. In that period, the policy developed under the administration of Laurence Guillemard and Cecil Clementi as British High Commissioner for the Malay States. This fact is prove of the influence of the empire's union policy in London, an implicit imperial strategy, in centralising the Malay States administration under the British High Commissioner. Although the Malay Rulers' position was returned in the State Council, their power was limited to financial administration of selected federal services. This raises the question of the imperial's intention in executing the decentralisation policy in FMS. The analysis of the FMS and Colonial Office documents shows that the execution of the decentralisation policy was a strategy by the British to form the Malayan Union under its control. The attempt was to combine the administration of the FMS colonial administration with the Straits Settlements and the Unfederated Malay States under the British High Commissioner.
\end{abstract}

Keywords and phrases: Malaysian history, imperial history, colonial administration, politics of development, Malayan Union 


\begin{abstract}
Abstrak. Artikel ini menilai semula hujah pelaksanaan dasar desentralisasi British sebagai suatu usaha untuk mengembalikan kuasa Raja-Raja Melayu dalam Majlis Mesyuarat Negeri (MMN) di Negeri-Negeri Melayu Bersekutu (NNMB). Tumpuan diberikan pada fasa awal pelaksanaan dasar ini iaitu setelah Majlis Mesyuarat Persekutuan (MMP) distruktur semula pada tahun 1927 sehingga pelaksanaannya pada tahun 1934. Dalam tempoh tersebut, dasar desentralisasi NNMB telah melalui proses pembentukan ketika pentadbiran Laurence Guillemard dan Cecil Clementi selaku Pesuruhjaya Tinggi British di Tanah Melayu. Proses ini membuktikan pengaruh dasar kesatuan empayar dari London sewaktu wujudnya strategi imperial yang tersirat untuk memusatkan pentadbiran Tanah Melayu kepada Pesuruhjaya Tinggi British. Walaupun kedudukan Raja-Raja Melayu dikembalikan dalam MMN, bidang kuasanya hanya terbatas dalam pentadbiran kewangan bagi jabatan perkhidmatan persekutuan yang ditetapkan. Hal ini demikian kerana MMP masih lagi mempunyai kuasa kawalan pentadbiran kewangan pada peringkat persekutuan. Justeru, apakah matlamat British yang sebenar dalam melaksanakan dasar desentralisasi di NNMB? Hasil kajian terhadap dokumen pentadbiran kolonial NNMB dan Pejabat Tanah Jajahan mendapati bahawa pelaksanaan dasar desentralisasi di NNMB merupakan strategi imperialisme British untuk membentuk Kesatuan Tanah Melayu di bawah kawalannya. Pentadbiran kolonial NNMB cuba digabungkan dengan Negeri-Negeri Selat serta NegeriNegeri Melayu Tidak Bersekutu dan diletakkan di tangan Pesuruhjaya Tinggi British.
\end{abstract}

Kata kunci dan frasa: sejarah Malaysia, sejarah imperial, pentadbiran kolonial, pembangunan politik, Kesatuan Tanah Melayu

\title{
Pengenalan
}

Negeri-Negeri Melayu Bersekutu (NNMB) merupakan satu daripada entiti politik dan ekonomi kolonial dalam kerangka British Malaya yang mula diwujudkan oleh pentadbir British pasca Perang Dunia Pertama. Kerangka ini merujuk kepada kesatuan pentadbiran kolonial antara NNMB, Negeri-Negeri Selat (NNS) serta negeri Johor, Kedah, Perlis, Kelantan dan Terengganu yang dikenali sebagai Negeri-Negeri Melayu Tidak Bersekutu (NNMTB) (rujuk Lampiran 1; CO 717/81 1931). Dalam konteks imperialisme British, kedudukan Malaya atau Tanah Melayu ialah sebagai Negeri Naungan atau Protectorates dalam empayar kolonial yang merupakan sebahagian daripada empayar British. Punca kuasa bagi kawalan British terhadap negeri-negeri Melayu adalah berdasarkan siri perjanjian antara British dengan Raja-Raja Melayu. Walaupun British menjamin kedaulatan Raja-Raja Melayu, hakikat sebenar pengiktirafan British tersebut hanya terbatas terhadap daulat baginda yang kebal daripada bidang kuasa mahkamah (CO 717/55/7 1927; CO 717/91 1932).

Sebelum pembentukan persekutuan NNMB, Emerson (1964), Khoo (1966), Allen (1964) dan Porter dan Stockwell (1987) telah mengesan perkembangan awal imperialisme British terhadap negeri-negeri Melayu di Pantai Barat 
pada akhir abad ke-19. Ketika perkembangan awal imperialisme British, ejenejen imperialis mula berperanan sebagai Residen pada peringkat negeri bagi memperkenalkan pentadbiran kolonial. Berdasarkan perkembangan ini, Emerson $(1964,114)$ dan Khoo $(1966,53)$ berhujah, faktor untuk melindungi ekonomi perdagangan merupakan justifikasi utama berlakunya gerakan imperialis di negeri-negeri Melayu, manakala Allen $(1964,44)$ pula lebih cenderung dengan hujah perkembangan perindustrian di Britain ialah faktor yang mendorong perkembangan imperialisme. Namun demikian, hasil kajian Allen terbatas dalam perbincangan berkaitan peranan imperialis yang dilaksanakan Frank Swettenham dan Hugh Clifford pada akhir abad ke-19. Meskipun berbeza pandangan, keempat-empat kajian ini bersetuju dengan pandangan bahawa pengenalan sistem Residen merupakan strategi imperialisme British pada akhir abad ke19 untuk mengukuhkan kawalannya terhadap negeri-negeri Melayu. Menurut Porter dan Stockwell (1987, 4), keperluan membentuk kerajaan kolonial di tanah jajahan merupakan strategi British untuk mewujudkan kestabilan politik dan kemakmuran ekonomi di tanah jajahan. Dalam isu ini, Allen (1964, 48-49) mendapati pengenalan sistem Residen di negeri-negeri Melayu bukanlah sesuatu yang asing dalam perkembangan imperialisme British kerana sistem yang sama turut dilaksanakan oleh pihak kolonial di India.

Penelitian terhadap hasil kajian awal menimbulkan persoalan "Bagaimana pentadbiran kolonial di negeri-negeri Melayu berkembang pada abad ke-20?". Isu ini telah dikupas dalam penulisan Emerson (1964), Ahmad Kamal Ariffin dan Suffian (2014) serta Andaya dan Andaya (2017). Ketiga-tiga kajian ini mendapati berlaku perkembangan penting dalam pentadbiran kolonial di negeri-negeri Melayu sejak akhir abad ke-19 iaitu setelah NNMB dibentuk menerusi Perjanjian Persekutuan 1895. Emerson $(1964,136)$ menghujahkan bahawa pembentukan NNMB merupakan satu usaha British untuk menyatukan pentadbiran Residen yang tidak seragam pada peringkat negeri, terutamanya pentadbiran jabatan perkhidmatan persekutuan berkaitan kehakiman, percukaian dan tanah. Oleh itu, jawatan Residen Jeneral diperkenalkan bagi memusatkan pentadbiran tersebut pada peringkat persekutuan. Berdasarkan pembentukan sistem pentadbiran persekutuan tersebut, Andaya dan Andaya (2017, 180) mendapati Residen British pada peringkat negeri telah mengetepikan kedudukan Raja-Raja Melayu dan Majlis Mesyuarat Negeri (MMN) dalam urusan pentadbiran. Masalah ini diselesaikan menerusi penubuhan Majlis Mesyuarat Persekutuan (MMP) pada tahun 1909 setelah Raja-Raja Melayu dibawa menyertainya dalam proses penggubalan undang-undang pada peringkat persekutuan. Ahmad Kamal Ariffin dan Suffian (2014) pula telah mengkaji perkembangan MMP yang berperanan sebagai pusat kawalan pentadbiran kolonial di NNMB. Walaupun begitu, hasil kajian tersebut mendapati kuasa penggubalan undang-undang persekutuan telah 
dipusatkan kepada Pesuruhjaya Tinggi British. Kesannya, kuasa Raja-Raja Melayu dalam MMN terhakis dan baginda Raja-Raja Melayu mula menimbulkan rasa tidak puas hati kepada Pejabat Tanah Jajahan dengan menuntut pelaksanaan desentralisasi. Oleh itu, dalam menyelesaikan masalah ini, Pejabat Tanah Jajahan bersetuju untuk melaksanakan dasar desentralisasi dengan menstruktur kembali MMP pada tahun 1927. Selain itu, Mohd Shazwan $(2019,113)$ berpandangan pelaksanaan dasar desentralisasi di NNMB juga merupakan langkah British untuk penyelesaian krisis kewangan NNMB yang dihadapi sejak awal tahun 1920-an. ${ }^{1}$

Beberapa pengkaji seperti Smith (1995), Milner (1987) dan Yeo (1971) berpendapat pelaksanaan dasar desentralisasi NNMB pasca 1927 merupakan langkah British bagi mengembalikan kedudukan Raja-Raja Melayu dalam MMN. Hal ini demikian kerana pada awal tahun 1920-an, Raja-Raja Melayu mula mempertikaikan pentadbiran terpusat oleh kerajaan persekutuan dan menuntut bidang kuasa yang sama seperti pemerintah di NNMTB (Emerson 1964, 162). Hasil kajian lepas telah membuktikan wujudnya agenda tersembunyi pihak British dalam mengembalikan kedudukan baginda dalam MMN dan melonggarkan pentadbiran terpusat pada peringkat persekutuan. Pandangan Smith $(1995,22-$ 23) misalnya menghujahkan wujudnya strategi imperialis dalam pelaksanaan dasar desentralisasi oleh British pada tahun 1930-an. Keraguan terhadap tujuan pelaksanaan dasar desentralisasi ini dikukuhkan lagi dengan pandangan Milner $(1987,774)$ yang menjelaskan pelaksanaan dasar desentralisasi bukan hanya bertujuan untuk memuaskan hati Raja-Raja Melayu tetapi merupakan strategi pihak British untuk membentuk persekutuan yang lebih luas daripada NNMB. Bahkan, beliau juga mendapati pelaksanaan dasar desentralisasi tidak memberikan kuasa pentadbiran mutlak kepada Raja-Raja Melayu ketika nasihat daripada pegawai kolonial diperlukan dalam MMN. Berdasarkan hujahan-hujahan tersebut timbul persoalan "Apakah strategi imperialisme yang dimaksudkan?" Kajian ini cuba menilai strategi imperialisme British dari London dalam proses pembentukan dasar desentralisasi di NNMB. Kajian ini mendapati pada akhir proses pembentukan dasar desentralisasi, pemusatan kuasa pentadbiran NNMB sebenarnya telah dialihkan secara implisit daripada kerajaan persekutuan kepada Pesuruhjaya Tinggi British.

\section{Mekanisme Pentadbiran Kolonial di NNMB}

Pembentukan persekutuan NNMB menerusi Perjanjian Persekutuan 1895 merupakan strategi imperialisme British untuk membentuk mekanisme pentadbiran kolonial yang terpusat pada peringkat persekutuan. Mekanisme ini membolehkan proses imperialisme British berlaku menerusi penurunan kuasa pentadbiran secara sah oleh Raja-Raja Melayu kepada ejen dan perwakilan 
kerajaan British yang dikenali sebagai Residen Jeneral, kemudiannya dikenali sebagai Ketua Setiausaha sejak tahun 1911 (Federated Malay States 1935). Perkembangan penting berlaku pada tahun 1909 apabila British berjaya memeterai Perjanjian Pembentukan Majlis Mesyuarat Persekutuan 1909 dengan Raja-Raja Melayu untuk menubuhkan MMP. Perjanjian ini juga merupakan satu lagi strategi British untuk membentuk alat pengabsahan undang-undang kolonial yang digubal berdasarkan dasar imperial dari London. Kesan mekanisme pentadbiran kolonial ini telah membolehkan British berperanan sebagai pemerintah de facto bagi NNMB manakala Raja-Raja Melayu dikatakan hanya duduk dan memerhatikan proses pentadbiran yang dilaksanakan (CO 717/81 1931).

Alasan untuk melindungi kepentingan masyarakat Melayu digunakan oleh British bagi mendapatkan persetujuan Raja-Raja Melayu untuk menubuhkan MMP. Walaupun begitu, matlamat di sebalik alasan tersebut adalah bagi mendapatkan persetujuan Raja-Raja Melayu untuk memberikan kuasa Presiden MMP kepada Pesuruhjaya Tinggi British. Perubahan ini secara langsung telah mengetepikan peranan Majlis Eksekutif dengan meletakkan peranan Residen Jeneral dan Residen British pada peringkat negeri sebagai penasihat kepada Pesuruhjaya Tinggi British. Aspek nasihat tersebut termasuklah berkaitan hal ehwal pentadbiran persekutuan dan untuk mengeratkan hubungannya dengan Raja-Raja Melayu dengan Pesuruhjaya Tinggi British. Setelah jawatan Ketua Setiausaha diperkenalkan bagi menggantikan jawatan Residen Jeneral pada tahun 1911, pentadbiran kolonial NNMB semakin terpusat pada peringkat persekutuan. Keadaan ini berlaku apabila Ketua Setiausaha diberikan kuasa untuk mengatasi keputusan Residen pada peringkat negeri. Namun demikian, bidang kuasa ini masih tertakluk kepada sebarang pindaan daripada Pesuruhjaya Tinggi British. ${ }^{2}$

Selain itu, kejayaan British membentuk MMP juga merupakan pencapaian imperialis dalam mengambil alih kuasa pentadbiran undang-undang daripada Raja-Raja Melayu. Menurut Ahmad Kamal Ariffin dan Suffian (2014, 3), pembentukan MMP bertepatan dengan dasar Pejabat Tanah Jajahan yang mahukan pentadbiran kolonial di NNMB dilaksanakan secara kesatuan. Peruntukan Artikel 8 dan 9 Perjanjian Pembentukan MMP 1909 memberi kuasa kepada MMP untuk meluluskan undang-undang di NNMB tanpa perlu merujuk kepada perkenan Raja-Raja Melayu terlebih dahulu. Walaupun begitu, kedudukan Raja-Raja Melayu diperlukan sebagai pengabsah bagi setiap undangundang yang diluluskan MMP. Oleh sebab itu, frasa "It is hereby enacted by the Rulers of the Federated Malay States in Council" digunakan British dalam setiap undang-undang yang diluluskan MMP (CAB 24/239/CP/81 1933; Ahmad Kamal Ariffin dan Suffian 2014, 8). Pengekalan kedudukan Raja-Raja Melayu 
dalam mekanisme pentadbiran kolonial di NNMB menyebabkan kerajaan British tidak mempunyai bidang kuasa langsung terhadap Negeri Naungan. Sungguhpun begitu, Akta Bidang Kuasa Asing 1890 menetapkan bidang kuasa kerajaan British perlu dilaksanakan menerusi badan perundangan tempatan (Great Britain 2020). Oleh sebab itu, British menggunakan Perjanjian Persekutuan 1895 dan Perjanjian Pembentukan MMP 1909 bagi mendapatkan persetujuan RajaRaja Melayu untuk memberikan British kuasa membentuk kerajaan persekutuan dan badan perundangan. Melalui kuasa perundangan MMP, Pesuruhjaya Tinggi British diberikan kuasa mengawal pentadbiran kewangan secara terpusat. Kawalan ini termasuklah bidang kuasa menggubal undang-undang berkaitan kewangan bagi membantu perkembangan ekonomi kolonial khususnya dalam sektor pertanian dan perindustrian. Kawalan kewangan ini termasuklah meluluskan peruntukan dana pinjaman peladang untuk merangsang pertumbuhan perladangan getah yang merupakan nadi ekonomi imperial di Tanah Melayu. Sehingga tahun 1912, MMP telah meluluskan sebanyak $\$ 1,643,761.35$ dana pinjaman untuk tujuan tersebut (Mohd Shazwan, Muhammad Aslah dan Mohd Samsudin 2017, 12). Kepentingan kawalan kewangan persekutuan tersebut disebabkan dasar British yang menjadikan pengumpulan lebihan kewangan sebagai sumber kekayaan NNMB. Tambahan lagi, NNMB merupakan pembiaya utama projek pembangunan kolonial bagi NNMTB dan NNS. Antara perbelanjaan yang menjadi beban kewangan NNMB pada awal tahun 1920-an ialah pembinaan tambak Johor, pembinaan pelabuhan Prai dan pinjaman pembinaan kereta api Siam yang merupakan imbalan British kepada kerajaan Siam kerana bersetuju untuk menyerahkan NNMTB kepadanya melalui Perjanjian Anglo-Siam 1909 (Mohd Shazwan 2019, 102).

\section{Pembentukan Dasar Desentralisasi oleh Laurence Guillemard}

Masalah kemelesetan ekonomi pasca Perang Dunia Pertama telah mendorong Laurence Guillemard, Pesuruhjaya Tinggi British di Tanah Melayu (19201927) membentuk dasar desentralisasi sejak tahun 1925. Beliau menggunakan kuasa Presiden MMP untuk mengusulkan pelaksanaan dasar desentralisasi bagi mengurangkan kuasa pentadbiran terpusat oleh Ketua Setiausaha kerajaan NNMB. Guillemard menggunakan alasan untuk mengembalikan kuasa dan peranan Raja-Raja Melayu dalam MMN untuk mendapatkan persetujuan baginda bagi melaksanakan desentralisasi. Namun demikian, alasan ini hanya melibatkan pengagihan kuasa pentadbiran Ketua Setiausaha kepada MMN. Sementara kuasa kawalan kewangan kerajaan NNMB masih lagi dalam bidang kuasa Presiden MMP. Tambahan lagi, pelaksanaan dasar ini juga memberi hak tunggal kepada Pesuruhjaya Tinggi British untuk berurusan secara terus dengan Setiausaha Tanah Jajahan bagi sebarang hal berkaitan pentadbiran kolonial di NNMB. 
Oleh sebab itu, Guillemard berhujah pelaksanaan dasar desentralisasi tersebut tidak akan mengubah kedudukan negeri dalam persekutuan, kerana pelaksanaan desentralisasi bertujuan untuk mengembalikan matlamat Perjanjian Persekutuan 1895 (Sel. Sec. 3114/1927 1927).

Langkah pengagihan kuasa pentadbiran Ketua Setiausaha kerajaan NNMB dalam dasar desentralisasi Guillemard melibatkan tiga tindakan utama. Pertama, membentuk Jawatankuasa Residen yang berperanan untuk menyediakan cadangan pengagihan kuasa pentadbiran persekutuan kepada negeri. Kedua, mengembalikan kedudukan Raja-Raja Melayu dalam MMN dan yang ketiga ialah mengembalikan kuasa pentadbiran kewangan Raja-Raja Melayu dalam MMN. ${ }^{3}$ Walaupun begitu, cadangan pengagihan kuasa pentadbiran persekutuan dalam dasar desentralisasi Guillemard tetap mengekalkan pentadbiran terpusat bagi jabatan perkhidmatan kerajaan utama seperti undang-undang dan mahkamah, tanah, perlombongan, buruh, kereta api, kastam dan eksais, pos dan telegraf. Pengekalan ini disebabkan keperluan untuk mentadbir jabatan-jabatan tersebut secara seragam pada peringkat persekutuan (Sel. Sec. 3114/1927 1927).

Jawatankuasa Residen turut dibantu Jawatankuasa Kewangan dalam merangka dasar desentralisasi NNMB untuk pertimbangan Guillemard. Ketetapan ini disebabkan setiap laporan interim berkaitan impak kewangan bagi proses penurunan kuasa pentadbiran persekutuan kepada negeri perlu dinilai oleh Jawatankuasa Kewangan. Setelah cadangan impak kewangan tersebut dinilai oleh Jawatankuasa Kewangan, cadangan ini diangkat sebagai dasar kewangan yang diluluskan dalam persidangan MMP. Di samping itu, Jawatankuasa Kewangan turut berperanan mengenal pasti dan melaporkan kedudukan kewangan NNMB, khususnya berkaitan kebarangkalian peningkatan bidang kuasa kewangan untuk MMN. Jawatankuasa ini dianggotai Penasihat Kewangan NNS dan NNMB, Bendahari NNMB dan Juruaudit Negara NNMB. Selain itu, Jawatankuasa Residen British juga berperanan mengenal pasti sebarang masalah pentadbiran kolonial yang berlaku di NNMB. ${ }^{4}$

Penelitian terhadap dasar desentralisasi Guillemard menunjukkan wujudnya strategi imperialisme British untuk meneruskan kawalan pentadbiran kewangan persekutuan. Walaupun terdapat langkah penurunan kuasa ke peringkat negeri, kawalan MMP terhadap pentadbiran kewangan MMN tetap wujud di sebalik dasar pentadbiran kewangan baharu yang diperkenalkan. Buktinya, dasar ini menetapkan bahawa setiap anggaran perbelanjaan sama ada pada peringkat persekutuan mahupun negeri perlu diabsahkan menerusi Enakmen Perbekalan yang diluluskan dalam persidangan MMP. Proses kelulusan ini turut melibatkan 
urusan kelulusan waran perbelanjaan dalam anggaran perbelanjaan persekutuan yang mesti disahkan oleh Ketua Setiausaha. Waran perbelanjaan negeri pula perlu disahkan Residen atau Setiausaha kepada Residen. ${ }^{5}$

Kepentingan kawalan kewangan persekutuan dalam dasar desentralisasi Guillemard merupakan bukti pengaruh neomerkantilisme dalam dasar ekonomi imperial di NNMB. ${ }^{6}$ Hal ini demikian kerana sejak awal tahun 1920-an kerajaan British mula menyalurkan modal dan bantuan kewangan kepada tanah jajahan untuk tujuan mempercepatkan pembangunan sumber ekonomi yang diperlukan Britain sebagai negara induk (Davis and Huttenback 1988, 30). Selain itu, pada tahun 1923, Guillemard bersetuju dengan cadangan Suruhanjaya Penghematan supaya kawalan kewangan persekutuan diperketatkan dalam pelaksanaan dasar desentralisasi agar pembiayaan pembangunan kolonial bagi negeri-negeri Melayu di luar persekutuan dapat diteruskan (HCO 545/1922 1923). Tambahan lagi, kawalan kewangan persekutuan juga diperlukan oleh British untuk membolehkan dana kewangan dari NNMB dapat disalurkan kepada kerajaan British bagi mengurangkan beban kewangan imperial kesan daripada Perang Dunia Pertama (CO 717/ 1 1920).

Pelaksanaan dasar desentralisasi Guillemard dianggap sebagai strategi British untuk menyatukan pentadbiran NNMB dengan pentadbiran NNS di tangan Pesuruhjaya Tinggi British yang berpusat di Singapura. Walaupun beliau menolak pandangan ini, perkembangan politik di Britain membuktikan perkara sebaliknya (Sel. Sec. 3114/1927 1927). Pada tahun 1927, Perdana Menteri Britain, Stanley Baldwin menyeru langkah kesatuan empayar bagi menyelesaikan masalah kebergantungan Britain terhadap sumber bahan mentah dari luar negara, khususnya produk makanan. Langkah ini melibatkan usaha kerajaan Britain mengikat komitmen ekonomi tanah jajahan yang berperanan sebagai pembekal sumber bahan mentah. Justeru pada tahun yang sama, kerajaan Britain telah menganjurkan Persidangan Pejabat Tanah Jajahan bagi menggubal dasar kolonial yang khusus untuk pembangunan tanah jajahan tropika yang terdiri daripada tanah jajahan berstatus Tanah Jajahan Mahkota, Negeri Naungan dan Wilayah Mandat. ${ }^{7}$

Seruan Baldwin ini seterusnya mempengaruhi pembentukan dasar kolonial Pejabat Tanah Jajahan ketika pentadbiran Leo Amery sebagai Setiausaha Tanah Jajahan (1924-1929). Menerusi dasar ini, sikap Amery terhadap idea kesatuan empayar dikatakan lebih cenderung untuk membentuk kerjasama antara tanah jajahan dalam membangunkan sumber bahan mentah berbanding terikat dengan orientasi metropolitan yang berpusat di London (Grayson 2006, 508-510). Oleh sebab itu, Setiausaha Tanah Jajahan lebih memihak kepada Guillemard berbanding George Maxwell (Ketua Setiausaha kerajaan NNMB) dalam pertikaian berkaitan 
isu kedudukan pentadbir kolonial tertinggi di NNMB, pemansuhan jawatan Ketua Setiausaha dan penyatuan pentadbiran jabatan perkhidmatan persekutuan dalam dasar desentralisasi di NNMB dalam pelaksanaan dasar desentralisasi oleh Guillemard (lihat Yeo 1981, 52; Philip 1972, 41).

\section{Penyusunan Semula MMP}

Kemuncak pelaksanaan dasar desentralisasi Guillemard berlaku pada tahun 1927 apabila MMP distruktur semula menerusi Perjanjian Penyusunan Semula MMP. Perjanjian ini melibatkan Guillemard sendiri selaku Pesuruhjaya Tinggi British di Tanah Melayu yang bertindak atas nama baginda Raja England dengan Pemerintah NNMB yang terdiri dari Perak, Selangor, Negeri Sembilan dan Pahang. Menerusi perjanjian ini, Raja-Raja Melayu tidak lagi menjadi ahli dalam MMP. Kekosongan ini digantikan dengan 11 orang ahli tidak rasmi yang dicalonkan Pesuruhjaya Tinggi British dengan perkenan baginda Raja England. Berdasarkan jumlah ini, seramai empat orang ahli tidak rasmi dipilih bagi setiap negeri dengan keutamaan diberikan kepada wakil berbangsa Melayu. Perjanjian ini turut merupakan satu lagi strategi imperialisme British untuk memusatkan pentadbiran persekutuan. Buktinya, perjanjian ini terus mengekalkan kedudukan Pesuruhjaya Tinggi British sebagai Presiden MMP dan hanya digantikan oleh Ketua Setiausaha ketika ketiadaan beliau dalam persidangan MMP. Artikel 9 perjanjian ini memberi kuasa kepada Pesuruhjaya Tinggi British untuk memanggil persidangan MMP sekurang-kurangnya sekali dalam setahun. Artikel 12 pula mengekalkan kuasa kawalan kewangan NNMB pada peringkat MMP apabila setiap anggaran pendapatan dan perbelanjaan perlu dibentangkan dan disahkan dalam persidangan MMP. Hanya menerusi kelulusan MMP, peruntukan kewangan secara sekali gus dapat disalurkan ke negeri. Walaupun Artikel 11 memberi kuasa kepada MMN untuk menggubal dan melaksanakan undang-undang pada peringkat negeri, artikel yang sama juga membataskan kuasa tersebut selagi tidak bertentangan dengan mana-mana peruntukan undang-undang yang diluluskan MMP pada peringkat persekutuan. $^{8}$

Alasan untuk mengembalikan kuasa Raja-Raja Melayu dalam MMN merupakan strategi Guillemard untuk mengeluarkan baginda daripada keahlian MMP. Perubahan ini telah mempengaruhi perubahan terhadap perintah tetap MMP, yang menyaksikan Residen British mula berperanan menjadi wakil bagi setiap Raja-Raja Melayu dalam persidangan MMP. Hal ini bermakna kedudukan RajaRaja Melayu pada peringkat persekutuan diambil alih oleh Residen British bagi menghubungkan kerjasama antara MMN dengan MMP. Namun, Residen dikehendaki berunding terlebih dahulu dengan Raja-Raja Melayu berkaitan agenda negeri yang ingin dibawa dalam persidangan MMP. Walaupun Raja- 
Raja Melayu tidak lagi mempunyai kedudukan dalam pentadbiran kolonial pada peringkat persekutuan, Pesuruhjaya Tinggi British masih mempunyai saluran lain bagi mengukuhkan hubungan imperialis dengan Raja-Raja Melayu. Oleh sebab itu, peranan Durbar dikembalikan sebagai majlis persidangan Raja-Raja Melayu yang turut dianggotai Pesuruhjaya Tinggi British, Ketua Setiausaha dan Residen. Durbar yang ditetapkan perlu bersidang sekurang-kurangnya sekali setahun dengan memberi tumpuan terhadap hal ehwal masyarakat Melayu dan negeri (Federated Malay States 1927a; 1927b). Kesan perubahan MMP dan struktur pentadbiran persekutuan ini akhirnya telah membolehkan Pesuruhjaya Tinggi British bertindak sebagai ketua pentadbir kolonial di Tanah Melayu (Federated Malay States 1927c).

\section{Dasar Desentralisasi oleh Cecil Clementi}

Pentadbiran Laurence Guillemard selaku Pesuruhjaya Tinggi British di Tanah Melayu dan Gabenor NNS tamat pada tahun 1927 dan kemudiannya digantikan oleh Hugh Clifford yang hanya bertugas selama dua tahun (1927-1930). Menurut Emerson $(1964,174)$ dan Philip $(1972,42)$, pentadbiran Clifford kurang mengetengahkan isu desentralisasi kerana beliau terpaksa bersara awal atas faktor kesihatan. Clifford kemudiannya digantikan oleh Cecil Clementi sejak tahun 1930 hingga 1934. Pentadbiran Clementi meneruskan strategi imperialis dalam dasar desentralisasi Guillemard untuk merealisasikan gagasan pentadbiran British Malaya yang seragam. Berbanding Guillemard, proses pembentukan dasar desentralisasi Clementi dipengaruhi secara langsung oleh Pejabat Tanah Jajahan yang diputuskan melalui dua persidangan Pejabat Tanah Jajahan pada 16 Mac 1931 dan 15 Mei $1931 .^{9}$

Ketika persidangan di Pejabat Tanah Jajahan pada 16 Mac 1931, Pejabat Tanah Jajahan telah mengarahkan Clementi untuk merangka sistem baharu bagi pentadbiran kolonial di Tanah Melayu. Namun begitu, Clementi berpandangan adalah sukar untuk membentuk persekutuan baharu di Tanah Melayu melainkan diwujudkan satu penguasa tunggal yang mempunyai bidang kuasa pentadbiran yang seragam untuk seluruh negeri di Tanah Melayu. Oleh sebab itu, beliau telah merangka satu strategi imperial bagi mendapatkan persetujuan Raja-Raja Melayu untuk menyerahkan bidang kuasa baginda Raja-Raja Melayu kepada Raja England melalui perintah dalam majlis mesyuarat di bawah Akta Bidang Kuasa Asing 1890. Caranya adalah melalui satu perjanjian antara Raja-Raja Melayu dengan wakil Raja England untuk keluar daripada pentadbiran persekutuan dan menyerahkan bidang kuasa kepada kerajaan persekutuan (CO 717/81 1931). 
Seterusnya ketika persidangan kedua pada 15 Mei 1931, Clementi berjaya membentuk dua strategi imperial bagi melaksanakan pentadbiran kolonial yang seragam di Tanah Melayu. Strategi pertama adalah dengan menyeragamkan pentadbiran jabatan kerajaan yang dikenali sebagai Malayan Department dan yang kedua melalui pembentukan kesatuan kastam (CO 717/81 1931). Ketika membentangkan cadangan dasar desentralisasinya, Clementi menjelaskan matlamatnya adalah untuk mengubah struktur pentadbiran kolonial persekutuan NNMB dengan cuba membawa NNMTB menyertai persekutuan yang baharu. Walaupun begitu, beliau tidak menolak bahawa matlamat ini sebenarnya merupakan kesinambungan daripada matlamat dasar desentralisasi ketika pentadbiran Laurence Guillemard. Asas bagi mencapai matlamat ini adalah untuk menstruktur kembali pentadbiran kolonial yang berasingan di NNMB, NNMTB dan NNS kepada satu bentuk pentadbiran seragam yang dikenali sebagai Malayan Department. Justeru, ketua-ketua jabatan kerajaan yang dilantik akan mempunyai kuasa pentadbiran eksekutif di NNS dan kuasa penasihat di negeri-negeri Melayu. Kesannya, kuasa pentadbiran terpusat pada peringkat kerajaan persekutuan NNMB dapat dilonggarkan, tetapi dipusatkan kepada Pesuruhjaya Tinggi British (CO 717/81 1931). Selain bersetuju dengan matlamat dasar desentralisasi Clementi, Setiausaha Tanah Jajahan turut menggesa untuk melaksanakan pembentukan kesatuan kastam (customs union) bagi membolehkan pemusatan pentadbiran kastam antara NNMB, NNMTB dan NNS dapat dilaksanakan. Ironinya, strategi ini sebenarnya satu bentuk kawalan terhadap hasil negeri yang disatukan pada peringkat persekutuan. Bahkan, strategi ini mempunyai matlamat untuk memberikan kuasa mutlak kepada Pesuruhjaya Tinggi British di Tanah Melayu bagi mengawal peruntukan dan pendapatan di seluruh negeri Melayu (CO 717/74 1930).

Dalam memenuhi perancangan tersebut, Setiausaha Tanah Jajahan menetapkan bahawa Clementi perlu mendapatkan persetujuan Raja-Raja Melayu bagi melaksanakan cadangan dasar desentralisasinya sebelum dikemukakan ke Kabinet Kerajaan British dan seterusnya diluluskan oleh Setiausaha Tanah Jajahan. Perancangan rapi dilaksanakan Clementi sebelum mendapatkan persetujuan Raja-Raja Melayu dengan mendapatkan sokongan pegawai kolonial di Tanah Melayu yang melibatkan Setiausaha Kolonial bagi kerajaan NNS dan Ketua Setiausaha bagi kerajaan NNMB. Beliau juga cuba mendapatkan sokongan daripada ahli tidak rasmi Majlis Mesyuarat Perundangan NNS dan ahli tidak rasmi MMP menerusi persidangan sulit yang diadakan di Singapura dan Kuala Lumpur. Setelah berjaya mendapat persetujuan daripada pegawai kolonial dan ahli tidak rasmi majlis mesyuarat NNS dan NNMB, barulah Clementi mengadakan Persidangan Durbar Raja-Raja Melayu pada 18 Ogos 1931 di Sri Menanti (CO 576/42 1931). 
Clementi seolah-olah cuba menyembunyikan matlamat imperialis dalam dasar desentralisasi yang dibentang di Pejabat Tanah Jajahan dengan memberi rasional kepada Raja-Raja Melayu tujuan dasar ini digubal ialah disebabkan kehendak baginda sendiri. Beliau tidak menjelaskan strategi pembentukan Malayan Department tetapi cuba meyakinkan Raja-Raja Melayu bahawa pentadbiran kerajaan perlu diseragamkan kerana terdapat sebahagian daripada jabatan perkhidmatan persekutuan seperti kereta api dan pos dioperasikan oleh syarikat komersial swasta. Bahkan, beliau turut memberi justifikasi keperluan untuk menyatukan pentadbiran pada peringkat persekutuan ialah disebabkan Raja-Raja Melayu sendiri tidak mempunyai hasrat untuk menguruskan pentadbiran jabatan kerajaan persekutuan melalui MMN (CO 576/42 1931). Berdasarkan penjelasan Clementi tersebut, dapatlah dirumuskan bahawa pelaksanaan dasar desentralisasi sebenarnya merupakan satu usaha tersirat untuk mengeluarkan Raja-Raja Melayu daripada pentadbiran dan badan perundangan persekutuan bagi merealisasikan strategi imperialis yang diputuskan di Pejabat Tanah Jajahan. Hujahan ini berdasarkan pelaksanaan dasar desentralisasi itu sendiri yang hanya memberikan kuasa mengurus belanjawan bagi sembilan jabatan perkhidmatan persekutuan kepada $\mathrm{MMN},{ }^{10}$ sedangkan kuasa pentadbiran terletak dalam tangan pegawai kolonial yang berpusat di Singapura.

Menerusi Durbar juga, Clementi berjaya mendapat persetujuan Raja-Raja Melayu untuk menyerahkan kuasa pentadbiran jabatan pos, kereta api dan kastam NNMB kepada pentadbiran Pesuruhjaya Tinggi British di Tanah Melayu. Ketigatiga jabatan ini kemudiannya dikenali sebagai Lembaga Pos Tanah Melayu, Lembaga Kereta Api Tanah Melayu dan Kesatuan Kastam Tanah Melayu. Alasan yang digunakan oleh Clementi bagi menyatukan pentadbiran ketiga-tiga jabatan adalah untuk membentuk pentadbiran perkhidmatan persekutuan yang seragam, sebagai penyelesaian masalah pentadbiran yang terpisah antara NNMB, NNMTB dan NNS. Rasionalnya ialah ketiga-tiga entiti politik ini saling bergantung antara satu sama lain dalam aktiviti ekonomi, terutamanya perkhidmatan kereta api NNMB yang merentas NNMTB dan NNS. Alasan untuk melaksanakan penyeragaman pentadbiran kastam pula adalah untuk menghapuskan halangan kastam di Tanah Melayu yang berbeza-beza mengikut entiti politik. Justeru menerusi kesatuan kastam pengumpulan, pendapatan persekutuan dapat dilaksanakan dengan lebih cekap. Tambahan pula, tujuan kesatuan kastam ini dilaksanakan adalah untuk menghapuskan cukai import bagi aktiviti perdagangan antara negeri di Tanah Melayu termasuklah NNS (CO 576/42 1931).

Pengabsahan pelaksanaan dasar desentralisasi oleh Clementi tidak terhenti pada peringkat Durbar sahaja kerana dasar tersebut perlu diabsahkan secara perundangan dalam persidangan MMP. Keterikatan proses pengabsahan ini 
disebabkan kedudukan NNMB dan NNMTB sebagai Negeri Naungan dalam Empayar British yang tidak membenarkan dasar imperial dilaksanakan secara terus dari London. Oleh itu, bagi membolehkan dasar imperial dilaksanakan dalam pentadbiran kolonial di Tanah Melayu, persetujuan Raja-Raja Melayu perlu diperoleh dan diabsahkan menerusi persidangan MMP (Federated Malay States 1923). Guillemard terdahulu telah menjelaskan keadaan ini dalam persidangan MMP pada tahun 1923:

[That] the Colonial Office control over the Government of the Federated Malay States in on the same lines as its control over the Government of the Colony; but it is much looser and it takes the form of advice rather than of direction... The Colonial Regulations do not apply in the Federated Malay States except in so far as the Government of the F.M.S. have voluntary applied them. (Federated Malay States 1923)

Penjelasan Guillemard ini membuktikan kepentingan MMP sebagai alat imperialis untuk mengabsahkan segala dasar imperialis British di NNMB. Oleh sebab itu, kedudukan MMP dikekalkan dalam dasar desentralisasi bagi membolehkan British meneruskan mekanisme pentadbiran kolonial di NNMB. Bahkan, tindakan British menambah bilangan ahli tidak rasmi MMP selepas pengunduran Raja-Raja Melayu sebenarnya merupakan strategi untuk mengalihkan perhatian awam terhadap hakikat pusat pentadbiran kolonial British di NNMB dipindahkan ke Singapura (CO 717/81 1931).

Clementi meneruskan strategi imperial Guillemard untuk menyatukan pentadbiran kolonial di Tanah Melayu bukanlah semata-mata untuk mengembalikan kedudukan Raja-Raja Melayu dalam MMN, tetapi sebagai strategi untuk menarik minat Raja-Raja Melayu NNMTB untuk menyertai persekutuan baharu yang menggantikan NNMB. Strategi ini dilaksanakan berdasarkan pengetahuan British terhadap sikap Raja-Raja Melayu NNMTB yang sedar tentang kedudukan Raja-Raja Melayu NNMB yang tidak mempunyai kuasa pentadbiran pada peringkat negeri. Justeru, menerusi langkah penurunan kuasa pentadbiran persekutuan kepada Raja-Raja Melayu NNMB di MMN masing-masing, British berharap dapat mempengaruhi Raja-Raja Melayu NNMTB untuk menyertai persekutuan (CO 717/81 1931). Strategi imperial ini diulas sebagai berikut:

[That] object of the scheme is the "untying of the knot" of the existing Federation. But the untying of that knot is only stage in the process of unifying Malaya, which, at present, is split up into a Colony, a federation of four states, and five separate and independent states. (CO 717/81 1931) 
Bagi meneruskan usaha penyatuan tersebut, Pejabat Tanah Jajahan telah dimaklumkan bahawa Clementi akan mula menggunakan MMP untuk mengabsahkan penurunan pentadbiran bagi jabatan perkhidmatan persekutuan yang berkaitan kepada MMN. Setelah kelulusan tersebut diperoleh, Clementi bercadang untuk menguatkuasakannya pada tahun 1933 dengan turut memulakan usaha mengorganisasi institusi MMN. ${ }^{11}$ Sir P. Cunliffe-Lister, Setiausaha Tanah Jajahan menilai keseluruhan cadangan dasar desentralisasi Clementi sebagai satu usaha untuk mewujudkan Malayan Union. Walaupun demikian, Cunliffe-Lister tidak meluluskan cadangan tersebut kerana beliau meragui keberkesanan dasar desentralisasi Clementi untuk membentuk satu persekutuan yang lebih besar melibatkan NNMTB. Keraguan ini berdasarkan hasil penilaian Cunliffe-Lister terhadap cadangan dasar desentralisasi Clementi seolah-olah tiada kaitan dengan usaha untuk membentuk persekutuan yang baharu. Cunliffe-Lister menjelaskan keraguan beliau:

As you pointed out in your speech to the Rulers, the community of trade and business interest has develop the federation into something very like amalgamation. All interest in the Federated Malay States have benefited from the prosperity which has resulted, ... In the circumstance I cannot but regret that you should have definitely announced that you intended to ask Federal Council to restore to the State Councils the control... It appears to me to be premature to consider what services should be restored to the State Council until the purpose aimed at in decentralization is settled, and general policy had received approval. ${ }^{12}$

Berdasarkan penjelasan ini, Setiausaha Tanah Jajahan telah mengarahkan Clementi untuk menghentikan pelaksanaan dasar desentralisasi tersebut sehingga cadangan penuh pelaksanaannya diputuskan oleh Kabinet Kerajaan British. Arahan ini telah menyebabkan persidangan MMP ditangguhkan dan secara tidak langsung, cadangan pelaksanaan dasar desentralisasi Clementi tidak dapat diluluskan (The Straits Times 1931a; 1931b).

\section{Masalah Pelaksanaan Dasar Desentralisasi}

Masalah penangguhan pelaksanaan dasar desentralisasi Clementi berlarutan sehingga pertengahan tahun 1932. Ketika dalam persidangan Parlimen British pada Mac 1932, Setiausaha Tanah Jajahan memaklumkan kepada Dewan Rakyat bahawa Pesuruhjaya Tinggi British di Tanah Melayu telah menyerahkan cadangan desentralisasi terhadap beberapa jabatan perkhidmatan persekutuan. Sungguhpun begitu, cadangan tersebut masih belum boleh diluluskan memandangkan Setiausaha Tanah Jajahan masih lagi menunggu laporan 
berkaitan kesan dasar tersebut terhadap sistem pentadbiran kolonial dan kewangan di NNMB (The Singapore Free Press and Mercantile Advertiser 1932a). Isu kesan dasar desentralisasi terhadap sistem pentadbiran kolonial timbul setelah pandangan masyarakat umum menilai dasar tersebut sebagai bukanlah bertujuan sepenuhnya mengembalikan kuasa Raja-Raja Melayu, tetapi satu usaha implisit memusatkan pentadbiran kolonial Tanah Melayu kepada Pesuruhjaya Tinggi British yang juga Gabenor NNS. Alasan Setiausaha Tanah Jajahan ini membuktikan wujudnya usaha pentadbiran Clementi untuk mengubah pusat pentadbiran NNMB dari Kuala Lumpur ke Singapura. Bahkan, alasan untuk mengembalikan kuasa MMN dengan menurunkan kuasa pentadbiran kewangan bagi jabatan perkhidmatan persekutuan tertentu sebenarnya merupakan langkah untuk mengaburi pandangan masyarakat umum terhadap matlamat imperial sebenar dalam dasar desentralisasi Clementi (Malaya Tribune 1932a). Pada masa yang sama, isu kesan kewangan pula mendapat perhatian setelah jawatankuasa berkaitan perubahan kewangan bagi dasar desentralisasi melaporkan tindakan menurunkan kuasa pentadbiran kewangan kepada MMN akan meningkatkan lagi kos kewangan berbanding sistem pentadbiran kewangan sedia ada. Masalah ini wujud apabila kerajaan persekutuan terpaksa menanggung beban kewangan untuk menampung perbelanjaan operasi persekutuan yang disatukan. Oleh sebab itu, pihak jawatankuasa telah menyarankan agar liabiliti kewangan persekutuan ini turut ditanggung oleh kerajaan negeri (The Straits Times 1932a).

Masalah penangguhan dasar desentralisasi Clementi juga disebabkan Setiausaha Tanah Jajahan yang masih belum berpuas hati berkaitan maklum balas NNMTB khususnya Kedah dan Johor yang mengkritik proses pelaksanaan dasar tersebut. Pemerintah NNMTB mengkritik bahawa cadangan perubahan struktur pentadbiran kolonial dalam dasar desentralisasi sebenarnya dicadangkan untuk NNMB, malah dipersetujui oleh Raja-Raja Melayu bagi NNMB. Namun begitu, cadangan dasar tersebut dipersembahkan kepada Raja-Raja Melayu NNMTB seolah-olah Sultan negeri Kedah, Johor, Terengganu, Kelantan dan Raja Perlis telah mempersetujuinya. Berdasarkan faktor ini juga, Setiausaha Tanah Jajahan menangguhkan kelulusan pelaksanaan dasar Clementi sehingga beliau berpuas hati dengan perancangan dasar desentralisasi yang lebih jelas serta mendapat respon dari Raja-Raja Melayu berkaitan kedudukan dasarnya (The Straits Times 1932b). Oleh sebab itu, Setiausaha Tanah Jajahan memaklumkan kepada Parlimen British bahawa, "I decline to express an opinion without the fullest information. The proposals will receive the full and unprejudiced consideration which their importance demands" (The Singapore Free Press and Mercantile Advertiser 1932b). 
Saranan Setiausaha Tanah Jajahan agar pandangan awam perlu diambil kira dalam pelaksanaan dasar desentralisasi menyebabkan Clementi menghadapi kritikan awam terhadap cadangan dasarnya. Keperluan pandangan awam ini disebabkan pelaksanaan dasar desentralisasi Clementi yang turut melibatkan jabatan perkhidmatan persekutuan berkaitan ekonomi, khususnya timah dan getah yang merupakan sumber pendapatan utama firma British di Tanah Melayu. Setiausaha Tanah Jajahan berpandangan bahawa adalah tidak wajar pentadbiran berkaitan industri timah dan getah diserahkan kepada MMN kerana pentadbiran terpusat sebelumnya lebih baik (Malaya Tribune 1932b). Persatuan British Malaya (Association of British Malaya) yang berpengkalan di London dan mantan Ketua Setiausaha bagi kerajaan NNMB (George Maxwell) turut mengkritik dasar desentralisasi Clementi sebagai usaha untuk memusatkan pentadbiran kolonial di tangan Pesuruhjaya Tinggi British. ${ }^{13}$ Maxwell mengkritik Clementi seolah-olah tidak memahami struktur pentadbiran kolonial yang berbeza di Tanah Melayu. Beliau berhujah bahawa masalah utama yang dihadapi pentadbiran Clementi untuk menggabungkan pentadbiran kolonial NNMB dengan NNMTB ialah perbezaan antara sistem Residen British di NNMB dengan Penasihat British di NNMTB. Maxwell menjelaskan bahawa Residen British di NNMB mempunyai kuasa eksekutif untuk menjalankan pentadbiran bagi pihak RajaRaja Melayu sementara Penasihat British di NNMTB hanya berperanan sebagai penasihat. Bahkan, kuasa pentadbiran Residen British diabsahkan menerusi badan perundangan yang diisytiharkan dalam gazet kerajaan. Walaupun begitu, beliau menegaskan bahawa kawalan British terhadap Tanah Melayu bukan terletak kepada dua sistem tersebut, tetapi kedudukan kuasa eksekutif yang diperturunkan Raja-Raja Melayu kepada pegawai British. Dalam kes ini, Pesuruhjaya Tinggi British mempunyai kuasa eksekutif di NNMB menerusi kedudukannya sebagai Presiden MMP, tetapi tidak di NNMTB (The Straits Times 1932c).

\section{Campur Tangan Pejabat Tanah Jajahan}

Masalah pelaksanaan dasar desentralisasi di NNMB cuba diselesaikan oleh Setiausaha Tanah Jajahan secara langsung dengan mengarahkan BrigadierGeneral Sir Samuel Wilson, Setiausaha Rendah Tetap Tanah Jajahan melawat Tanah Melayu. Misi lawatan Wilson bertujuan untuk menyelesaikan pembentukan cadangan dasar desentralisasi Cecil Clementi yang masih berlarutan. Lawatan ini melibatkan kerjasama antara Wilson dengan Clementi, Raja-Raja Melayu dan komuniti awam bagi meneliti pengaruh aspek politik, pentadbiran, kewangan dan ekonomi dalam pelaksanaan dasar desentralisasi (CAB 24/239/CP/81 1933). Campur tangan Pejabat Tanah Jajahan dalam pelaksanaan dasar desentralisasi di NNMB juga jelas ketika Setiausaha Tanah Jajahan membuat keputusan untuk 
menangguh kelulusan pelaksanaan dasar ini sehingga laporan lawatan Wilson diserahkan kepada beliau (The Straits Times 1932d).

Hasil daripada lawatannya, Wilson telah mencadangkan agar Raja-Raja Melayu NNMB diberikan kuasa untuk mentadbir hal ehwal domestik pada peringkat negeri. Langkah penurunan kuasa pentadbiran yang dicadangkan dalam Persidangan Durbar pada tahun 1931 perlu dikekalkan dengan melibatkan jabatan perkhidmatan persekutuan berkaitan pertanian, koperasi, pendidikan, elektrik, perhutanan, perubatan, perlombongan, kerja raya dan veterinar. Selain disebabkan permintaan Raja-Raja Melayu untuk mentadbir kerajaan negeri, langkah ini perlu dilaksanakan sebagai strategi imperial untuk melindungi pentadbiran kolonial secara langsung di Tanah Melayu. Tambahan lagi, Wilson menegaskan Raja-Raja Melayu telah dimaklumkan sejak awal lagi bahawa kedudukan baginda Raja-Raja Melayu akan dikembalikan dalam MMN. Sekiranya langkah ini tidak dilaksanakan, beliau khuatir Raja-Raja Melayu akan mula meragui niat kerajaan British dalam pelaksanaan dasar desentralisasi. Selain itu, Wilson juga bersetuju bahawa penurunan kuasa ini akan membolehkan kerajaan NNMB dan NNMTB bekerjasama ke arah satu kesatuan pentadbiran kolonial (CAB 24/239/CP/81 1933).

Laporan Wilson turut mencadangkan agar penurunan kuasa pentadbiran kewangan dalam dasar desentralisasi dilaksanakan melalui tiga fasa. Fasa pertama melibatkan kawalan MMP terhadap peruntukan kewangan untuk jabatan perkhidmatan persekutuan yang diserahkan kepada pentadbiran MMN. Kawalan yang dimaksudkan ialah setiap anggaran peruntukan yang diperlukan MMN perlu diluluskan pada peringkat persekutuan dalam persidangan MMP dengan tujuan untuk mengawal kos operasi bagi setiap jabatan perkhidmatan persekutuan yang diserahkan kepada MMN. Fasa kedua pula melibatkan penurunan kuasa kepada MMN bagi mentadbir segala hasil pendapatan negeri yang tidak diperlukan untuk perbelanjaan pada peringkat persekutuan. Langkah ini dilaksanakan untuk melonggarkan kawalan MMP terhadap pentadbiran hasil pendapatan negeri dan dalam masa yang sama, sebagai langkah untuk membantu MMN menyeimbangkan anggaran perbelanjaannya. Fasa ketiga pula melibatkan langkah penurunan kuasa kepada MMN untuk mentadbir sumber pendapatan dan hak untuk mengenakan cukai bagi menampung perbelanjaan negeri tanpa bergantung dengan peruntukan kewangan daripada MMP. Walaupun cadangan ini menunjukkan seolah-olah MMN akan diberikan autonomi penuh terhadap pentadbiran kewangannya, kawalan pentadbir kolonial pada peringkat persekutuan tetap wujud apabila Wilson mencadangkan agar Bendahari Persekutuan perlu menjadi ahli dalam MMN bagi setiap negeri dalam persekutuan NNMB. Malah, MMN tidak dibenarkan mengeluarkan pinjaman negeri tanpa kelulusan MMP (CAB 24/239/CP/81 1933). 
Selain itu, Wilson mencadangkan agar jawatan Ketua Setiausaha kerajaan NNMB dihapuskan sebagai salah satu langkah utama dalam dasar desentralisasi. Langkah ini perlu dilaksanakan bagi membolehkan kuasa kanun dan pentadbiran berkaitan negeri dapat dikembalikan kepada Raja-Raja Melayu pada peringkat MMN. Walaupun begitu, cadangan ini mendapat bantahan daripada komuniti perniagaan di NNMB melainkan jawatan tersebut digantikan dengan jawatan pentadbir kanan yang berperanan sebagai pembantu kepada Pesuruhjaya Tinggi British bagi menyelaras dasar dan hal ehwal persekutuan. Oleh sebab itu, Wilson mencadangkan dalam laporan beliau agar jawatan Ketua Setiausaha digantikan dengan satu jawatan yang mempunyai taraf sebagai ketua operasi kerajaan persekutuan (CAB 24/239/CP/81 1933).

Laporan Wilson turut mendapat kritikan daripada Sir F.A. Swettenham dan Sir G. Maxwell yang berkongsi pandangan bahawa jawatan Ketua Setiausaha bagi kerajaan NNMB tidak perlu dihapuskan. Kedua-duanya juga berpandangan bahawa matlamat pelaksanaan dasar desentralisasi yang dicadangkan oleh Wilson sebenarnya merupakan usaha untuk memusatkan pentadbiran kolonial di Tanah Melayu ke tangan Pesuruhjaya Tinggi British. Tambahan lagi, sebagai bekas Ketua Setiausaha bagi kerajaan NNMB, Maxwell berpandangan penurunan kuasa pentadbiran bagi jabatan perkhidmatan persekutuan hanya akan melemahkan mekanisme pentadbiran kolonial pada peringkat persekutuan (The Singapore Free Press and Mercantile Advertiser 1933a; The Straits Times 1933a). Kritikan ini turut mengukuhkan pandangan terhadap pelaksanaan dasar desentralisasi akan menyebabkan kerajaan persekutuan NNMB tidak mempunyai ketua pentadbir persekutuan melainkan Pesuruhjaya Tinggi British di Tanah Melayu. Cadangan Laporan Wilson ini secara langsung akan memindahkan pusat pentadbiran NNMB ke Singapura kerana Pesuruhjaya Tinggi British juga merupakan Gabenor bagi NNS (CO 717/81 1931). Walaupun demikian, sebagai pendahulu bagi pelaksanaan dasar desentralisasi di NNMB, Guillemard bersetuju sepenuhnya dengan Laporan Wilson (The Straits Times 1933b). Sokongan Guillemard ini sebenarnya tidak menghairankan kerana Laporan Wilson sebenarnya merupakan kesinambungan daripada cadangan dasar desentralisasi Clementi yang meneruskan usaha Guillemard sebelumnya.

Kemuncak campur tangan Pejabat Tanah Jajahan dalam pembentukan dasar desentralisasi di NNMB berlaku sewaktu persidangan Dewan Rakyat, Parlimen British pada 14 Julai 1933. Menerusi persidangan ini, ketika membentangkan anggaran perbelanjaan kolonial, Sir Philip Cunliffe-Lister selaku Setiausaha Tanah Jajahan menjelaskan beliau bersetuju untuk melaksanakan cadangan dasar desentralisasi seperti dalam Laporan Wilson dengan alasan laporan tersebut telah diterima secara keseluruhannya di Tanah Melayu. Beliau juga menolak tuduhan 
pemusatan kuasa oleh Pesuruhjaya Tinggi British dalam dasar desentralisasi tersebut dengan alasan Laporan Wilson tidak mengubah langsung kedudukan dan kuasa pentadbiran Pesuruhjaya Tinggi British. Malah, Cunliffe-Lister turut berhujah bahawa Laporan Wilson sebenarnya merupakan penyelesaian bagi masalah pentadbiran terpusat di NNMB yang tidak memberi manfaat terhadap kepentingan tempatan (The Singapore Free Press and Mercantile Advertiser 1933b).

\section{Pelaksanaan Dasar Desentralisasi NNMB}

Dasar desentralisasi NNMB dilaksanakan sepenuhnya pada tahun 1934 dengan melibatkan perubahan terhadap struktur politik persekutuan. Perubahan ini dilakukan oleh pentadbiran Clementi dengan menggunakan MMP untuk meluluskan perpindahan pentadbiran kewangan bagi 10 jabatan perkhidmatan persekutuan kepada pentadbiran negeri (lihat Lampiran 2). Walaupun begitu, pentadbiran bagi jabatan persekutuan yang diserahkan kepada negeri akan diketuai seorang ketua pada peringkat persekutuan yang turut berperanan sebagai penasihat tanpa sebarang kuasa eksekutif dalam MMN (Federated Malay States 1934a). Sungguhpun demikian, Clementi telah memulakan persediaan pelaksanaan dasar desentralisasi lebih awal iaitu sebaik sahaja beliau menerima kelulusan daripada Setiausaha Tanah Jajahan pada tahun 1933. Namun begitu, tidak banyak pelaksanaan dasar desentralisasi yang mampu dilakukan oleh Clementi antara tahun 1933 hingga 1934 kerana beliau terpaksa meletakkan jawatan sebagai Pesuruhjaya Tinggi British di Tanah Melayu atas faktor kesihatan pada tahun 1934 (Federated Malay States 1934b). Pada peringkat awal pelaksanaan dasar desentralisasi, pentadbiran Clementi telah melaksanakan langkah awal desentralisasi dengan menubuhkan Malayan Establishment Office dan Malayan Postal Union seperti yang dicadangkan dalam Laporan Wilson (Federated Malay States 1933a).

Malayan Establishment Office merupakan sistem perkhidmatan awam baharu yang dicadangkan dalam Laporan Wilson sebagai langkah dalam desentralisasi pentadbiran di NNMB. Sistem ini bertujuan untuk menyeragamkan pentadbiran Malayan Civil Service (MCS) di Tanah Melayu. Oleh itu, perkhidmatan pegawai kolonial di bawah skim MCS di NNMB, NNMTB dan NNS dapat disatukan di bawah satu perkhidmatan (CAB 24/239/CP/81 1933). Pesuruhjaya Tinggi British di Tanah Melayu mempunyai pengaruh langsung terhadap perkhidmatan Malayan Establishment Office sewaktu pusat operasinya dipusatkan di Singapura (Federated Malay States 1933b). Pada peringkat awal, J.A. Hunter, pegawai MCS dari London telah dihantar bagi mengorganisasi pejabat Malayan Establishment Office di Singapura (The Singapore Free Press and Mercantile Advertiser 1933c). 
Namun begitu, operasi Malayan Establishment Office hanya mula dikuatkuasakan pada 1 Januari 1934 setelah kerajaan NNS, NNMB dan NNMTB bersetuju untuk melaksanakan sistem perkhidmatan ini dengan menanggung liabiliti membayar kos operasi dan latihan bagi pegawai kolonial dalam skim Malayan Establishment Office kepada Perbendaharaan Kolonial (Malaya Tribune 1933).

Walaupun begitu, penubuhan Malayan Postal Union yang bertujuan untuk menyatukan pentadbiran jabatan pos NNMB dengan NNS memerlukan persetujuan Raja-Raja Melayu bagi NNMB. Justeru, pentadbiran Clementi telah merangka perjanjian antara British dengan Raja-Raja Melayu bagi membolehkan negeri Melayu yang dinaungi British menyertai kesatuan pos tersebut. Kesatuan pos ini ditadbir oleh seorang pegawai kolonial yang dilantik sebagai Ketua Pengarah Pos dan Telegraf Tanah Melayu. Bagi membolehkan pegawai ini mempunyai bidang kuasa di NNMB, Penasihat Undang-Undang telah menggunakan MMP untuk meluluskan Rang Undang-Undang Gelaran Jabatan Pos (Pindaan). Undangundang ini turut menguatkuasakan perubahan jawatan Penolong Setiausaha Hal Ehwal Pos kepada Pengarah Pos. Selain itu, Penasihat Undang-Undang NNMB turut menggunakan MMP untuk meluluskan Rang Undang-Undang Pejabat Pos (Pindaan) 1933 yang bertujuan membolehkan setem dari NNS, Johor, Kedah, Perlis, Kelantan dan Terengganu digunakan untuk tujuan pos di NNMB. Bagi menyeragamkan prinsip penggunaan setem ini, kerajaan NNS turut menguatkuasakan undang-undang yang sama (Federated Malay States 1933a).

Pelaksanaan dasar utama desentralisasi NNMB hanya dilakukan pada bulan Ogos 1934 setelah Andrew Caldecott menggantikan tempat Clementi selaku Pesuruhjaya Tinggi British. Caldecott telah menggunakan MMP untuk meluluskan peruntukan kewangan secara sekali gus untuk negeri Perak, Selangor, Negeri Sembilan dan Pahang. Kelulusan resolusi ini juga menjadi titik permulaan kepada pelaksanaan dasar desentralisasi yang menyeluruh di NNMB yang melibatkan 37 jenis perbelanjaan jabatan perkhidmatan persekutuan yang diserahkan kepada MMN (lihat Lampiran 2). Pada masa yang sama, kelulusan ini turut memberi kuasa kepada MMN untuk menentukan peruntukan kewangan yang diterima untuk setiap jabatan perkhidmatan yang diserahkan oleh kerajaan persekutuan. Namun demikian, agihan peruntukan tersebut perlu dimasukkan dalam Rang Undang-Undang Perbekalan untuk diluluskan oleh MMN. Pada tahun 1934, MMP telah meluluskan peruntukan kewangan sebanyak $\$ 5,656,000$ untuk diserahkan kepada MMN dan sebanyak \$26,001,000 pula diperuntukkan pada tahun 1935. Pemangku Ketua Setiausaha bagi kerajaan NNMB menjelaskan kepada ahli MMP bahawa kerajaan persekutuan masih lagi mempunyai kuasa untuk mentadbir keseluruhan peruntukan kewangan di NNMB. Lantaran itu, MMP diperlukan untuk meluluskan peruntukan kewangan tersebut (Federated Malay States 1934c). 


\section{Kesimpulan}

Tahun 1927 sehingga 1934 merupakan fasa awal pelaksanaan dasar desentralisasi di NNMB. Sepanjang tempoh ini, pengaruh aspirasi kesatuan empayar dari London wujud dalam proses pembentukan dasar desentralisasi menerusi campur tangan Pejabat Tanah Jajahan. Berdasarkan perkembangan ini, tumpuan pada peringkat awal pelaksanaan dasar desentralisasi hanya terbatas dengan penstrukturan semula mekanisme pentadbiran kolonial di NNMB. Proses ini berlaku semenjak MMP distruktur semula pada tahun 1927 dan ketika Laporan Wilson diluluskan oleh Setiausaha Tanah Jajahan sebagai dasar desentralisasi NNMB pada tahun 1933. Walaupun begitu, Laporan Wilson sebenarnya merupakan kesinambungan cadangan dasar desentralisasi oleh Clementi sejak tahun 1931 lagi. Sesuai dengan fasa awal pelaksanaannya, laporan tersebut telah meneruskan cadangan Clementi untuk menstruktur semula MMN menerusi penurunan kuasa pentadbiran kewangan dan cadangan untuk memusatkan pentadbiran kolonial Tanah Melayu di Singapura. Walaupun Setiausaha Tanah Jajahan menafikan wujudnya langkah pemusatan kuasa oleh Pesuruhjaya Tinggi British, proses pengalihan pentadbiran terpusat berlaku secara implisit sewaktu kesemua ketua pentadbir jabatan perkhidmatan persekutuan ditempatkan di Singapura (CO 717/81 1931). Namun begitu, usaha untuk menubuhkan sebuah persekutuan baharu dengan melibatkan NNMTB terhenti setelah Raja-Raja Melayu bagi NNMTB tidak bersetuju dengan langkah penggabungannya dengan NNMB dan NNS. Masalah ini berlaku disebabkan kebimbangan Raja-Raja Melayu bagi NNMTB terhadap pemusatan pentadbiran kolonial di Singapura yang akan menggugat kedudukan kedaulatan baginda Raja-Raja Melayu pada peringkat negeri (Yeo 1971, 201).

Sungguhpun begitu, Raja-Raja Melayu bagi NNMB lebih awal telah bersetuju dengan dasar desentralisasi tersebut ketika Persidangan Dubar pada tahun 1931. Persidangan ini digunakan oleh Clementi untuk merealisasikan strategi imperial dalam dasar desentralisasi untuk menyatukan pentadbiran persekutuan. Strategi yang dimaksudkan adalah untuk mendapatkan persetujuan Raja-Raja Melayu bagi membentuk jabatan persekutuan baharu yang turut melibatkan NNMTB dan NNS. Jabatan kerajaan tersebut ialah Malayan Establishment Office, Malayan Postal Union, Lembaga Pos Tanah Melayu, Lembaga Kereta Api Tanah Melayu dan Kesatuan Kastam Tanah Melayu. Selain itu, bagi membolehkan Pesuruhjaya Tinggi British mempunyai bidang kuasa sebagai ketua eksekutif tunggal di NNMB, Clementi turut melaksanakan strategi menghapuskan jawatan Ketua Setiausaha dan menurunkan kuasa pentadbiran jawatan tersebut kepada negeri. Melalui pelaksanaan strategi tersebut, British berjaya mencapai matlamat kesatuan empayar setelah Raja-Raja Melayu bersetuju untuk menurunkan kuasa 
membentuk pentadbiran terpusat kepada British. Kesannya, pentadbiran jabatan kerajaan baharu berkaitan pentadbiran dan kegiatan ekonomi berjaya dikawal oleh Pesuruhjaya Tinggi British. Di samping itu, pengekalan institusi Raja-Raja Melayu juga merupakan sebahagian daripada strategi imperialisme British bagi mendapatkan pengabsahan kuasa pentadbiran kolonial yang menjadi alat kepada penjajahan. Bahkan berdasarkan pengalaman British sendiri, pengekalan institusi beraja secara langsung membolehkan British mengawal rakyat raja daripada memberontak melawan pihak kolonial (Smith 1995, 14-15).

\section{Penghargaan}

Kajian ini dilaksanakan menerusi tajaan Hadiah Latihan Cuti Belajar UKM/ KPM (PT), SLAB KPM(PT) Bil. 438/2018/10 dan Dana Projek TAP-K005755. Kajian ini turut dibantu oleh Arkib Negara Malaysia, The National Archives, London dan Perpustakaan Tun Seri Lanang, Universiti Kebangsaan Malaysia. Penulis merakamkan penghargaan kepada dua penilai yang tidak dikenali atas komen dan cadangan mereka.

\section{Nota}

1. Kesan dasar kewangan oleh British yang berbelanja melebihi pendapatan mengakibatkan kerajaan NNMB menghadapi krisis kewangan antara tahun 1920 hingga 1924. Pada tahun 1922, Suruhanjaya Penghematan melaporkan operasi pentadbiran kerajaan persekutuan gagal mengawal kewangan dengan baik dan terlalu memberi perhatian terhadap pembangunan kerja raya. Pada tahun 1921, hutang ditanggung kerajaan persekutuan adalah sebanyak $\$ 45.75$ juta, berbanding pendapatan sebanyak \$4.5 juta. Lihat Mohd Shazwan $(2019,103)$ untuk huraian lanjut.

2. Appendix A. No. 39 of 1925. Decentralisation and the Political Development of the Federated Malay States (Sel. Sec. 3114/1927 1927).

3. Ibid.

4. Appendix B. No. 9 of 1926. Statement by High Commissioner on Present Position with Regard to Proposed Policy of Decentralisation and the Political Development of the Federated Malay States (Sel. Sec. 3114/1927 1927).

5. Appendix C. No. 28 of 1926. Report of a Committee Appointed by His Excellency the High Commissioner to Make Recommendations in Regard to Financial Devolution (Sel. Sec. 3114/1927 1927).

6. Neomerkantilisme adalah doktrin ekonomi yang mula mempengaruhi dasar ekonomi imperial sejak akhir abad ke-19 dan mencapai puncaknya pada tahun 1920-an. Idea ekonomi ini mempengaruhi dasar campur tangan kerajaan British terhadap institusi politik di tanah jajahan bagi menguasai sumber ekonominya. Neomerkantilisme turut membentuk sistem merkantil yang menjadikan tanah jajahan sebagai pembekal bahan 
mentah dan pasaran ekonomi untuk import dari negara induk. Lihat Earle (1925) dan Mohd Shazwan, Muhammad Aslah dan Mohd Samsudin (2017) untuk huraian lanjut.

7. Radio broadcast by the Prime Minister, Stanley Baldwin on Empire Day, 24 May 1927 (Wiener 1972, 2954).

8. Appendix F. Agreement for the Re-Constitution of the Federal Council, 1927 (Sel. Sec. 3114/1927 1927).

9. Note of Conference at the Colonial Office on 16th March 1931, Concerning a Proposed New Constitution for Malaya. Lihat juga Note of Conference at the Colonial Office, 15 May 1931 dalam CO 717/81 (1931).

10. Jabatan yang terlibat ialah Pertanian, Koperasi, Pendidikan, Elektrik, Perhutanan, Perubatan, Perlombongan, Kerja Raya dan Veterinar (CO 576/41 1931).

11. Constitutional Changes in Malaya. Notes of a conference held in the Secretary of State's room on Monday, 7 December 1931 dalam CO 717/81 (1931).

12. Correspondence from P. Cunliffe-Lister to Federated Malay States. High Commissioner, 12 January 1932 dalam CO 717/81 (1931).

13. The Straits Times, "An undesirable change", 28 July 1932; The Straits Times, "Decentralisation proposals in Malaya", 14 December 1932.

\section{Lampiran}

\section{Lampiran 1}

Perubahan sempadan politik Tanah Melayu selepas pelaksanaan dasar desentralisasi

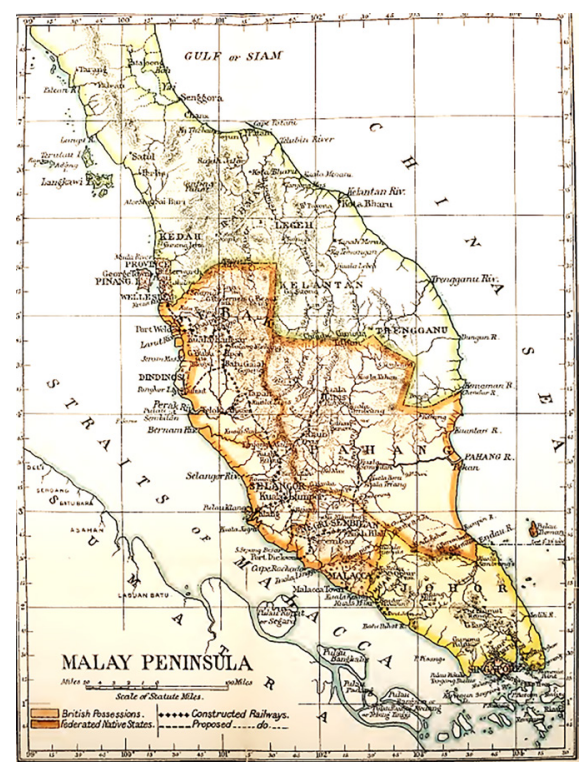

Ilustrasi 1. Peta Tanah Melayu tahun 1902

Sumber: Belfield, H.C. 1902. Handbook of the Federated Malay States. London: Edward Stanford. 


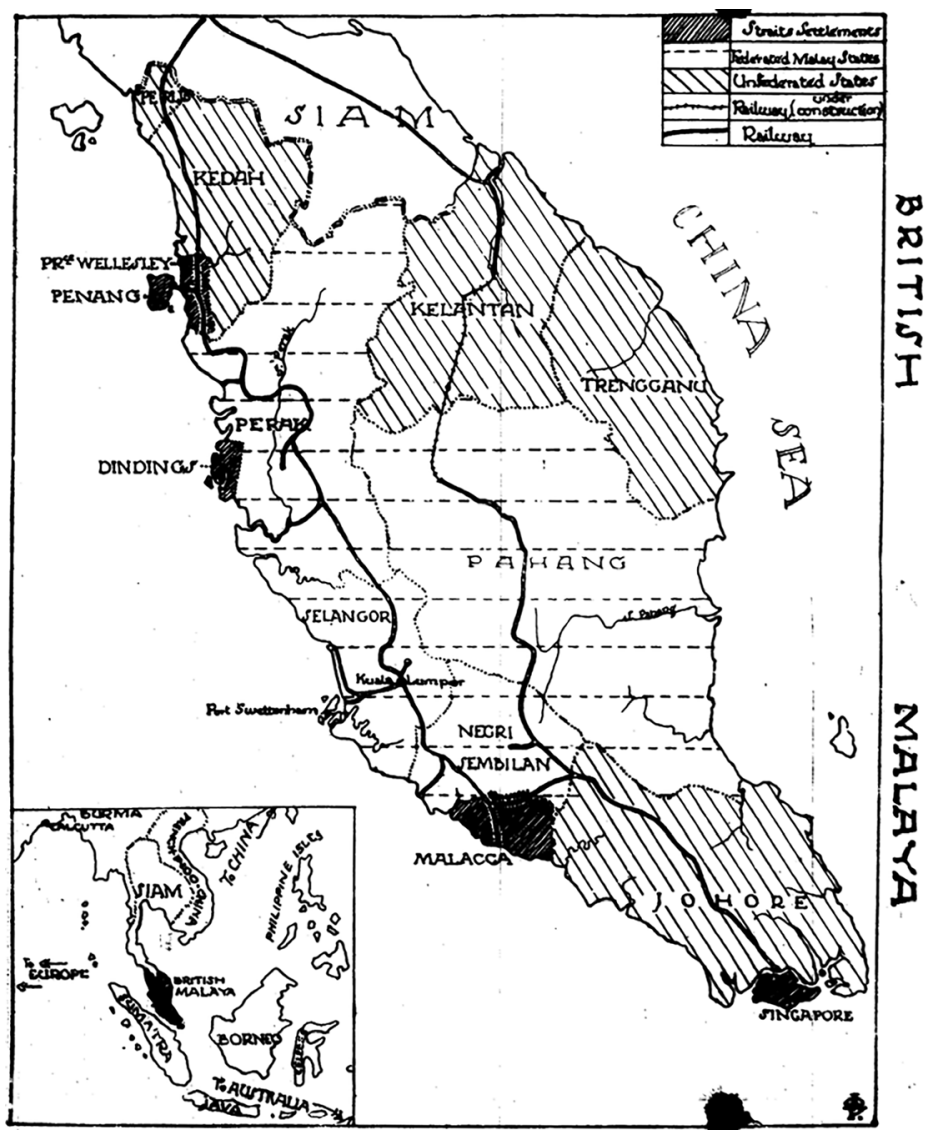

Ilustrasi 2. Peta Tanah Melayu tahun 1927

Sumber: CO 273/539. 1927. British Imperialism in Malaya.

\section{Lampiran 2}

(Shorthand Report of the Proceedings of the Federal Council, 27 th August 1934)

\section{SERVICES ALLOCATED TO STATES UNDER ARTICLES 12 OF AGREEMENT FOR RECONSTITUTION OF FEDERAL COUNCIL}

\section{SCHEDULE.}

1. Political Pensions and Compassionate Allowance;

2. The Ruler and Chiefs;

3. The Resident;

4. Civil Service; 
5. Agricultural Department;

6. Chinese Secretariat;

7. Clerical Service;

8. Courts;

9. District and Land Office and Settlement Officers;

10. Drainage and Irrigation Department;

11. Drainage and Irrigation, Annual Recurrent;

12. Drainage and Irrigation, Special Services;

13. Education;

14. Electrical;

15. Fire bridge, Registrar of Motor Vehicles and Miscellaneous;

16. Forest;

17. Game Warden;

18. Government Plantations and Public Gardens;

19. Indian Interpreters;

20. Malayan Establishment Office;

21. Marine;

22. Medical and Health Services;

23. Mines;

24. Miscellaneous Services;

25. Museum;

26. Post and Telegraphs;

27. Prisons;

28. Public Work Department;

29. Public Work, Annual Recurrent;

30. Public Work, Special Services;

31. Purchase of Land;

32. Registrar of Titles;

33. Sanitary Boards;

34. Town Planning;

35. Transport;

36. Vehicles Department;

37. Veterinary. 


\section{Bibliografi}

Ahmad Kamal Ariffin Mohd Rus and Suffian Mansor. 2014. Pengukuhan penguasaan British di Negeri-Negeri Melayu Bersekutu: Analisis dua perjanjian Majlis Mesyuarat Persekutuan, 1909 dan 1927. In Sejarah dan kesarjanaan, eds. Suffian Mansor, S. Sundara Raja, Arba'iyah Mohd Nor and Ahmad Kamal Ariffin Mohd Rus, 1-21. Kuala Lumpur: Jabatan Sejarah Universiti Malaya.

Allen, J.D.V. 1964. Two imperialist: A study of Sir Frank Swettenham and Sir Hugh Clifford. Journal of the Malaysian Branch of the Royal Asiatic Society 37(1): 41-73. Andaya, B.W. and Andaya, L.Y. 2017. A history of Malaysia. 3rd Ed. London: Palgrave. Belfield, H.C. 1902. Handbook of the Federated Malay States. London: Edward Stanford. CAB 24/239/CP/81. 1933. Report of Brigadier-General Sir Samuel Wilson, Permanent Under-Secretary of State for the Colonies on his visit to Malaya 1932. London: The National Archives.

CO 273/539. 1927. British imperialism in Malaya. Selangor, Malaysia: Perpustakaan Tun Seri Lanang.

CO 576/42. 1931. Federated Malay States. Proceedings of Durbar held at Sri Menanti on Tuesday, 18 August. Selangor, Malaysia: Perpustakaan Tun Seri Lanang.

CO 717/1. 1920. Telegram from the High Commissioner for the Malay states to the Secretary of State for the Colonies. 10 January. Selangor, Malaysia: Perpustakaan Tun Seri Lanang.

CO 717/55/7. 1927. Imperial preference. Selangor, Malaysia: Perpustakaan Tun Seri Lanang.

CO 717/74. 1930. Kedah. Uniformity in fundamental laws in Malaya. Selangor, Malaysia: Perpustakaan Tun Seri Lanang.

CO 717/81. 1931. Devolution in the F.M.S. Selangor, Malaysia: Perpustakaan Tun Seri Lanang.

CO 717/91. 1932. Legal status of the Malay States. Selangor, Malaysia: Perpustakaan Tun Seri Lanang.

Davis, L.E. and Huttenback, R.A. 1988. Mammon and the pursuit of empire: The economic of British imperialism. Cambridge: Cambridge University Press.

Emerson, R. 1964. Malaysia: A study in direct and indirect rule. Kuala Lumpur: University of Malaya Press.

FCO 141/16583. 1923-1926. Singapore: Decentralization; Memoranda of W.G. Maxwell (Chief Secretary to government, Federated Malay States) in chronological order. London: The National Archives.

Federated Malay States. 1935. Report of the Chief Secretary to government for the year 1934. Kuala Lumpur: F.M.S. Government Press. 1934a. Shorthand report of the proceedings of the Federal Council. 23 October. Selangor, Malaysia: Perpustakaan Tun Seri Lanang.

. 1934b. Shorthand report of the proceedings of the Federal Council. 2 July. Selangor, Malaysia: Perpustakaan Tun Seri Lanang. 1934c. Shorthand report of the proceedings of the Federal Council. 27 August. Selangor, Malaysia: Perpustakaan Tun Seri Lanang. 
1933a. Shorthand report of the proceedings of the Federal Council. 31 June. Selangor, Malaysia: Perpustakaan Tun Seri Lanang.

1933b. Shorthand report of the proceedings of the Federal Council. 30-31 October. Selangor, Malaysia: Perpustakaan Tun Seri Lanang.

. 1927a. Shorthand report of the proceedings of the Federal Council. 28 February.

Selangor, Malaysia: Perpustakaan Tun Seri Lanang.

. 1927b. Shorthand report of the proceedings of the Federal Council. 23 May.

Selangor, Malaysia: Perpustakaan Tun Seri Lanang.

. 1927c. Shorthand report of the proceedings of the Federal Council. 8 August.

Selangor, Malaysia: Perpustakaan Tun Seri Lanang.

1923. Shorthand report of the proceedings of the Federal Council. 11 July.

Selangor, Malaysia: Perpustakaan Tun Seri Lanang.

Grayson, R.S. 2006. Imperialism in conservative defence and foreign policy: Leo Amery and the Chamberlains, 1903-39. The Journal of Imperial and Commonwealth History 34(4): 505-527. https://doi.org/10.1080/03086530600991423

HCO 545/1922. 1923. The final report of the Retrenchment Commission. Kuala Lumpur: Arkib Negara Malaysia.

Khoo, K.K. 1966. The origin of British administration in Malaya. Journal of the Malaysian Branch of the Royal Asiatic Society 39(1): 52-91.

Malaya Tribune. 1933. The Wilson report, 30 October.

1932a. Decentralisation, 11 May.

1932b. Decentralisation policy, 13 June.

Milner, A.C. 1987. Colonial records history: British Malaya. Modern Asian Studies 21(4): 773-792. https://doi.org/10.1017/S0026749X00009318.

Mohd Shazwan Mokhtar. 2019. Di sebalik krisis kewangan Negeri-Negeri Melayu Bersekutu, 1920-1924. Kajian Malaysia 37(2): 95-119. https://doi.org/10.21315/ $\mathrm{km} 2019.37 .2 .5$

Mohd Shazwan Mokhtar and Mohd Samsudin. 2017. "Trade war": Sekatan perdagangan Jerman di Negeri-Negeri Melayu Bersekutu, 1914-1918. Akademika 87(1): 75-89. https://doi.org/10.17576/akad-2017-8701-06

Mohd Shazwan Mokhtar, Muhammad Aslah Akmal Azmi and Mohd Samsudin. 2017. Perkembangan sistem perdagangan merkantilisme di Negeri-Negeri Melayu Bersekutu (1909-1913). Jebat: Malaysian Journal of History, Politics and Strategic Studies 42(2): 1-26.

Philip, L.F.-S. 1972. Malay precedence and the federal formula in the Federated Malay States, 1909 to 1939. Journal of the Malaysian Branch of the Royal Asiatic Society 45(2): 29-50.

Porter, A.N. and Stockwell, A.J. 1987. British imperial policy and decolonization, 193864. Vol. 1. London: The Macmillan Press LTD. https://doi.org/10.1007/978-1-34918769-0

Sel. Sec. 3114/1927. 1927. Speech made in the Federal Council on the subject of decentralization and the political development of the Federated Malay States. Kuala Lumpur: Arkib Negara Malaysia.

Smith, S.C. 1995. British relations with the Malay Rulers from decentralization to Malayan independence 1930-1957. Kuala Lumpur: Oxford University Press. 
The Singapore Free Press and Mercantile Advertiser. 1933a. Sir Frank Swettenham condemns new policy, 24 April.

1933b. Decentralisation in Malaya, 7 August. 1933c. Untitled, 28 August.

1932a. Decentralisation. Further particulars wanted at home, 18 March. 1932b. Decentralisation in Malaya, 23 April.

The Straits Times. 1933a. New policy: Sir G. Maxwell return to the attack, 13 July. .1933b. I entirely agree, 3 May.

1932a. Decentralisation proposal in Malaya, 14 December.

1932b. Financial aspects of decentralisation, 5 July.

1932c. Undesirable change, 28 July.

1932d. Sir Samuel Wilson's mission, 26 May.

1931a. Is decentralisation to be reconsidered?, 27 December.

1931b. Has London called a halt?, 28 December.

Great Britain. 2020. Foreign Jurisdiction Act 1890 (c. 37). London: The National Archives.

Retrieved from http://www.legislation.gov.uk/ukpga/Vict/53-54/37/contents (accessed 1 July 2020)

Wiener, J.H., ed. 1972. Great Britain: Foreign policy and the span of empire 1689-1971; A documentary history. Vol. 4. New York: Chelsea House Publishers.

Yeo, K.W. 1981. The Guillemard-Maxwell power struggle, 1921-1925. Journal of the Malaysian Branch of the Royal Asiatic Society 54(1): 48-64.

1971. British policy towards the Malay in the Federated Malay States, 19201940. PhD diss., Australian National University. 